\title{
Technology acceptance model for the intention to use advanced business application software among Chinese business school students
}

\author{
Wai-Ming To, Linda S. L. Lai, Vincent W. S. Leung \\ Macao Polytechnic Institute
}

\begin{abstract}
Business schools strive to improve students' analytical skills by incorporating advanced business application software courses into their curricula. This study examined how business school students perceived the ease of using the software and the usefulness of using the software in learning. The study also explored whether and how students' perceived ease of use and usefulness of the software affected their attitude towards the use of business software and their intention to use the software. Data were collected from 159 Chinese business school students in a higher education institution in Macao. Results showed students generally agreed the software was easy to learn and use, and they agreed the software was useful. The results of structural equation modeling showed that perceived ease of use was directly and indirectly related to attitude towards the use of business software through its effect on perceived usefulness, whereas attitude towards the use of business software strongly affected the intention to use the software.
\end{abstract}

\section{Introduction}

In this era of big data, business firms require their employees to collect, filter, analyse, and interpret a vast amount of data to understand business situations and make effective management decisions. Hence, apart from meeting the basic job requirements by being graduates of business schools with specific grade-point averages, business firms expect applicants to be computer literate and have the ability to use advanced business application software for decision making. Paradoxically while students, including business school students, are social technology savvy, as evidenced by their use of information and communication technologies (ICTs) such as Facebook, YouTube, WhatsApp, WeChat, and Twitter on smartphones and laptops (Gosper, Malfroy, \& McKenzie, 2013), they are frequently unprepared and unwilling to use ICT technology as a tool to tackle business problems (Creighton, Kilcoyne, Tarver, \& Wright, 2006; McCloskey \& Bussom, 2013). This observation is in contrast to the fact that most high schools have offered basic computer courses, such as introduction to computers and the internet, introduction to Microsoft Office (including Word, PowerPoint and Excel), and informatics for the past decade (Asai, 2011; Maria de Fátima \& Alves, 2007). According to a survey conducted by the United Nations Educational, Scientific and Cultural Organization (UNESCO, 2014), nearly all countries in Australasia include integrated objectives or courses on basic computer skills at primary, lower secondary and upper secondary levels of education as a part of national curriculum. Nevertheless, a significant gap exists between the ICT proficiency level of students expected by university teachers and the actual ICT skills of first year university students (Ballantine, Larres, \& Oyelere, 2007; Fitzgerald, 2004). To remedy such a situation, some universities offer a required lower-level course that includes ICT application as part of its syllabus, whilst other universities offer subject specific ICT courses to all students (McCloskey \& Bussom, 2013).

Chau (2001) studied the influence of computer self-efficacy and computer attitude on students' intention to use basic computer software such as Microsoft Word, at the tertiary level. He reported that computer selfefficacy has no significant effect on perceived ease of use and a very small significant effect on perceived usefulness, whereas computer attitude has moderate significant associations with perceived ease of use and perceived usefulness. Gainey and Sanchez (2013) surveyed 197 first year students to determine their knowledge of Microsoft Word, PowerPoint, Excel, and Access in a business school in the United States. Most of these students indicated they had already used Microsoft Word and PowerPoint in high school on a regular basis and felt comfortable with basic applications. However, a large percentage of these students did not possess the same comfort level with Excel and Access, and many of them had never created a formula in an Excel file. Gainey and Sanchez (2013) suggested that university teachers may focus more on the application of Excel, Access, and other emerging internet-based technologies. Mandal, Flosi, and Large (2016) explored the impact of adopting the latest education technologies, such as MyITLab and Blackboard, on students' learning of basic computer software. Mandal et al. (2016) reported that students preferred selfdirected learning of software over rigid, teacher-centered classroom activities. 
In addition to basic computer courses, business schools require students to learn advanced business application software such as Peachtree for accounting, SAS for e-commerce, or IBM SPSS for management and business research in their senior years. Peachtree is very user friendly, flexible, and widely adopted in small businesses, and many business schools teach it in accounting information system courses (Hayes, Cook, \& LaRosa, 2011). In database marketing courses, IBM SPSS is the most popular advanced business application software for analysing survey data, while some business schools use SAS statistical software (Teer, Teer, \& Kruck, 2007). However, few studies have explored how business school students view advanced business application software after completing advanced computer courses. Hence, this study aimed to evaluate how business school students perceive the ease of using the software and the usefulness of using the software in learning or mastering business knowledge, as well as to test whether and how the technology acceptance model (TAM) can be used to predict students' intention to use the software.

\section{Literature review and hypotheses}

TAM, as its name implies, is a theoretical model that explains user acceptance of a ICT technology (Davis, Bagozzi, \& Warshaw, 1989). The model suggests that user acceptance of a new ICT technology is primarily determined by two factors: (1) perceived ease of use, and (2) perceived usefulness. Perceived ease of use is defined as the degree to which the user believes that using the technology will be free from effort (i.e., less input). Perceived usefulness is defined as the degree to which the user believes that using the technology will enhance her/his job performance (i.e., more output). In TAM, perceived ease of use is an antecedent of perceived usefulness, whilst both perceived ease of use and perceived usefulness significantly influence user attitude towards the use of a technology. Attitude towards the use of the technology is defined as the degree of favorable or unfavorable perceptions towards using the technology and is not tied to any specific beliefs about the technology. Attitude towards the use of the technology and perceived usefulness are related to behavioural intention to use the technology (Davis et al., 1989; Dillon \& Morris, 1996).

The applicability of TAM has been demonstrated in diverse ICT technologies such as word processing and spreadsheets (Chau, 1996; Roberts \& Henderson, 2000), email (Davis, 1989; Gefen \& Straub, 1997; Roberts \& Henderson, 2000), and the World Wide Web (Fenech, 1998; Lederer, Maupin, Sena, \& Zhuang, 2000). In recent years, TAM and its extended versions have been applied to e-shopping (Celik \& Yilmaz, 2011), mobile advertising (Muk \& Chung, 2015), general use of technology in learning and teaching (Atif, Richards, Busch, \& Bilgin, 2015; Behrend, Wiebe, London, \& Johnson, 2011; Chiu \& Tsai, 2014; Juan et al., 2018; Schroff, Deneen, \& Ng, 2011; Teo, 2008, Teo, Fan, \& Du, 2015; To \& Tang, 2019; Wong, Teo, \& Russo, 2012), and e-learning and m-learning (Fathali \& Okada, 2018; Im, Kim, \& Han, 2008).

Other than TAM, the task-technology fit (TTF) model addresses the utilisation of ICT technologies from a different perspective (Goodhue \& Thompson, 1995). Goodhue and Thompson (1995) argued that an ICT technology will be used when its functions and features meet or fit the task requirements of users. In other words, rational and experienced users would choose the ICT technologies that enable them to carry out the tasks most effectively and have better job performance. ICT technologies that do not meet task requirements would not be used. TTF and its extension models have been used in organisational studies and for goaloriented activities (Dishaw \& Strong 1999; Goodhue \& Thompson 1995; Lee et al., 2007).

The major advantage of the original TAM over other models such as the theory of reasoned action (Fishbein \& Ajzen, 1975), the theory of planned behaviour (Ajzen, 1985), and some extended TAM approaches, is its simplicity but still sufficient power to predict user acceptance of a ICT technology accurately (Davis et al., 1989; Edmunds, Thorpe, \& Conole, 2012; Venkatesh, 2000; Yousafzai, Foxall, \& Pallister, 2010). TAM is widely used by researchers to explore students' acceptance of ICT technology in learning environments (Edmunds et al., 2012; Park, Nam, \& Cha, 2012; Teo, 2008; Teo et al., 2015; To \& Tang, 2019), while some other competing models, such as TTF and its extensions, focus on the utilisation of ICT technology for enhancing job performance in organisational studies (Goodhue \& Thompson, 1995; Lee, Cheng, \& Cheng, 2007). The key components of TAM are shown in Figure 1. 


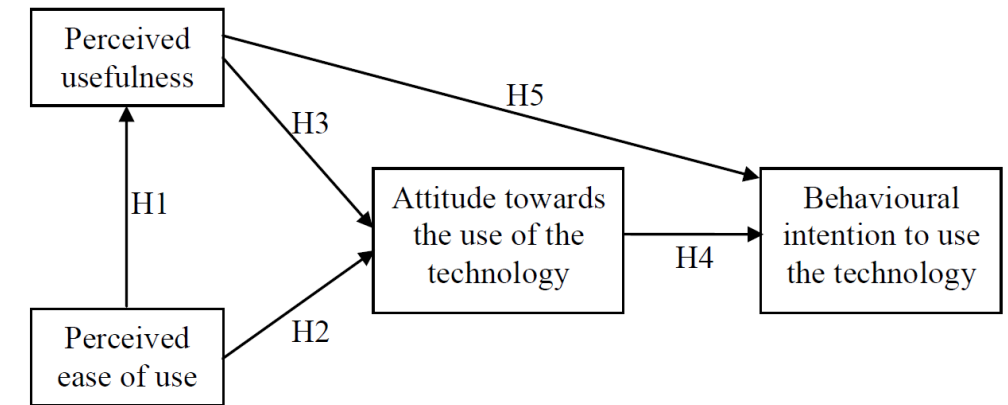

Figure 1. TAM model (adopted from Davis et al., 1989)

Figure 1 shows the relationships among perceived ease of use, perceived usefulness, attitude towards the use of the technology, and behavioural intention to use the technology. Following the suggestion by Davis et al. (1989), we posit the following five hypotheses:

H1. Perceived ease of use positively influences perceived usefulness.

H2. Perceived ease of use positively influences attitude towards the use of the technology.

H3. Perceived usefulness positively influences attitude towards the use of the technology.

H4. Attitude towards the use of the technology positively influences behavioural intention to use the technology.

H5. Perceived usefulness positively influences behavioural intention to use the technology.

Computer self-efficacy and facilitating conditions are considered antecedents of perceived ease of use (Behrend et al., 2011; Gu, Lee, Suh, 2009). Computer self-efficacy is defined as the degree to which the user believes that $\mathrm{s}$ /he has the ability to perform a specific task or job using a computer technology (Behrend et al., 2011; Gu et al., 2009). Facilitating conditions refer to the extent to which the user believes that an organisation's physical and technical infrastructure is available for performing the task (Gu et al., 2009). As the target respondents were senior-year business school students, who had taken at least a basic computer course in their junior years, and Chau (2001) indicated that computer self-efficacy has no significant effect on perceived ease of use at the upper tertiary level, computer self-efficacy was excluded in the present study. Further, the institution provided the necessary physical and technical infrastructure for supporting student learning advanced business application software. Facilitating conditions were also excluded in the study.

Amongst TAM studies, several researchers argued that gender can influence perceived usefulness and perceived ease of use (Gefen \& Straub, 1997; Teo et al., 2015), and possibly moderate the relationships between perceived ease of use and attitude towards the use of the technology, as well as between perceived usefulness and attitude towards the use of the technology (Im et al., 2008; Wong et al., 2012). Gefen and Straub (1997) found that females' rating of perceived ease of use (e-mail in their case) was lower than males' rating, whilst females' rating of perceived usefulness was higher than males' rating. However, Wu and Tsai (2006) reported there was no significant difference in perceived usefulness when using ICT between university students of different gender groups. Im et al. (2008) and Wong et al. (2012) reported that gender did not moderate the relationships between perceived ease of use and attitude towards the use of the technology and between perceived usefulness and attitude towards the use of the technology, probably due to the ubiquitous nature of computer and ICT in recent years. Nevertheless, we posit the following two hypotheses as suggested by Gefen and Straub's (1997) study:

H6. Female students' rating of perceived ease of use is lower than male students' rating.

H7. Female students' rating of perceived usefulness is higher than male students' rating.

\section{Method}

\section{Population and sample}

The study aimed to understand how business school students evaluate the use of advanced business application software and to test whether TAM can explain students' intention to use advanced business 
application software such as Peachtree, SAS, or IBM SPSS in this setting. Thus, the population of the study included all senior-year business school students who attended courses in advanced business application software in a higher education institution in Macao. The total number of students was 216, comprised of 93 accounting students, 23 e-commerce students, and 100 management students. In the second-to-last lecture of advanced business application software courses, students were invited to participate in the questionnaire survey voluntarily. The questionnaire was anonymised and data were kept confidential. These procedures were utilised to uphold research ethics and integrity and enhance the reliability of the survey. Many students completed and returned the questionnaires during the class hour. Some students took the questionnaires home and returned the completed questionnaires the next week. In total, 159 completed and usable questionnaires were obtained: a response rate of $73.6 \%$.

\section{Instrument}

The questionnaire comprised two sections. The first section asked students to rate their agreement with items assessing perceived ease of use, perceived usefulness, attitude towards the use of advanced business application software, and behavioural intention to use the software. Items were adapted from Davis (1989) and Schroff et al. (2011) and rated on a 7-point Likert scale (1 = strongly disagree and $7=$ strongly agree $)$. Perceived ease of use had 4 items. A sample item being: "It was easy for me to become skillful at using the software interface". Perceived usefulness had four items. An example being: "Using the software increased productivity in my coursework". Attitude towards the use of advanced business application software had three items. A sample item was: "Using the software provided me with a lot of enjoyment". Behavioural intention to use the software had four items. An example was: "I intend to use the software in future jobs". The Cronbach's alpha values of perceived ease of use, perceived usefulness, attitude towards the use of the software, and behavioural intention to use the software were $0.90,0.86,0.84$, and 0.87 respectively, which were higher than the threshold of 0.7 as recommended by Nunnally and Bernstein (1994). Items of the four constructs are shown in Appendix A.

The second section contained eight questions. Five were used for demographic information, namely: gender, age, year of study, specialisation, and place of residence. The three other questions asked the respondent about ownership of a computer and ICT devices (such as smart phone, tablet/iPad, laptop, and desktop computer), the number of hours per day spent (in total) using those devices, and the number of hours per day spent surfing the internet.

\section{Data analysis}

Simple statistics were calculated to determine how students evaluate the ease of use and usefulness of advanced business application software. Unpaired $t$-tests and analyses of variance (ANOVAs) were performed to investigate whether demographic characteristics such as gender, age group, specialisation, and place of residence influence students' perceptions, attitude and behavioural intention. Confirmatory factor analysis was performed with IBM SPSS AMOS 24.0 using the maximum likelihood algorithm to test whether the hypothesised measurement model fits the collected data, as well as determine the convergent and discriminant validity of the constructs. Four goodness-of-fit indices, namely, the normed Chi-square $\left(\chi^{2} / d f\right)$, non-normed fit index (NNFI), comparative fit index (CFI), and root mean square error of approximation (RMSEA), were used to evaluate the model fit (Hair, Anderson, Tatham, \& Black, 2006; Hooper, Coughlan, \& Mullen, 2008; Hu \& Bentler, 1999). Hair et al. (2006), and Hu and Bentler (1999) suggested the following cut off values for model fit indices: $\chi^{2} / d f \leq 3.0$, NNFI $\geq 0.95, \mathrm{CFI} \geq 0.95$, and RMSEA $\leq 0.08$. The convergent and discriminant validity of the constructs were assessed using average variance extracted (AVE) and correlations (Hair et al., 2006). Structural equation modeling was performed to examine the applicability of TAM in this context. The same four fit indices $\left(\chi^{2} / d f\right.$, NNFI, CFI, and RMSEA) were used to assess the structural model.

\section{Results}

Of the 159 usable surveys returned, 61 (38.4\%) were from males and $98(61.6 \%)$ were from females. Ninety-one $(57.3 \%)$ of them were in the age group from 22 to 24 , followed by $48(30.1 \%)$ in the age group from 20 to 22 . One hundred and nineteen $(74.8 \%)$ were year 4 students and $40(25.2 \%)$ were year 3 students. The highest percentage specialised in management $(50.3 \%)$ and the majority of them were local students (73.0\%). Table 1 presents the demographic profile of the students. 
Table 1

Demographic profile of students $(N=159)$

\begin{tabular}{llr}
\hline Variable & Category & Frequency \\
\hline Gender & male & $61(38.4 \%)$ \\
& female & $98(61.6 \%)$ \\
Age & 20 to $<22$ & $48(30.1 \%)$ \\
& 22 to $<24$ & $91(57.3 \%)$ \\
& 24 or above & $20(12.6 \%)$ \\
Year & 3 & $40(25.2 \%)$ \\
& 4 & $119(74.8 \%)$ \\
Specialisation & & $61(38.4 \%)$ \\
& Accounting & $18(11.3 \%)$ \\
& e-Commerce & $80(50.3 \%)$ \\
Place of residence & Management & $116(73.0 \%)$ \\
& Macao & $42(26.4 \%)$ \\
& Mainland China & $1(0.6 \%)$ \\
\hline
\end{tabular}

When asked about how many types of computer and ICT devices they have, all students responded with at least one type of device and more than half responded with three or four types of devices. A more detailed analysis showed that 147 students had smart phones, 89 had tablets/iPads, 101 had laptops, and 106 had desktop computers. Most students spent 2 to 8 hours a day using the devices and 1 to 4 hours a day surfing the internet as shown in Table 2.

Table 2

Ownership and use of computer and ICT devices $(N=159)$

\begin{tabular}{lrr}
\hline Item & Category & Frequency \\
\hline Computer and ICT device & 1 type & $13(8.2 \%)$ \\
& 2 types & $48(30.1 \%)$ \\
& 3 types & $58(36.5 \%)$ \\
& 4 types & $40(25.2 \%)$ \\
I normally spend __ in total using the device(s) & $1-2 \mathrm{hrs} /$ day & $20(12.6 \%)$ \\
& $2-4 \mathrm{hrs} /$ day & $54(34.0 \%)$ \\
& $4-8 \mathrm{hrs} /$ day & $57(35.8 \%)$ \\
& $>8 \mathrm{hrs} /$ day & $28(17.6 \%)$ \\
& $<1 \mathrm{hr} /$ day & $9(5.7 \%)$ \\
I normally spend __ surfing the internet & $1-2 \mathrm{hrs} /$ day & $53(33.3 \%)$ \\
& $2-4 \mathrm{hrs} /$ day & $55(34.6 \%)$ \\
& $4-8 \mathrm{hrs} /$ day & $37(23.3 \%)$ \\
& $>8 \mathrm{hrs} /$ day & $5(3.1 \%)$ \\
\hline
\end{tabular}

The descriptive statistics of the eight items of perceived ease of use and perceived usefulness are shown in Table 3. One-sample $t$-tests indicated that all mean scores were significantly greater than the midpoint of 4.0 ( $t$-values $\geq 3.50, p<0.001)$, except the third item of perceived ease of use, "Learning to use the software was easy to me" rated by the female group. The $t$-test results showed that students in general agreed that using advanced business application software was rather free from effort and using the technology could enhance their performance. When the mean scores of the male group were compared with those of the female group, the results revealed that the mean scores of the first three items for perceived ease of use of the male group were significantly greater than that of the female group ( $t$-values $\geq 2.77, p<0.01$ ), whilst no significant difference was observed between the mean scores of the fourth item of perceived ease of use (PEOU4) and items for perceived usefulness of the male group and those of the female group ( $t$-values $\leq$ $1.87, p>0.05)$. Hence, H6 was mostly supported, whilst $\mathrm{H} 7$ was not supported. 
Table 3

Means and standard deviations of perceived ease of use (PEOU) and perceived usefulness (PU) items

\begin{tabular}{|c|c|c|c|c|}
\hline Item & Category & $M(S D)$ & $\begin{array}{l}\text { One sample } t \text {-test } \\
\text { test value }=4.0 \\
t \text {-value ( } p \text {-value) }\end{array}$ & $\begin{array}{c}p \text {-value of } \\
\text { unpaired } t \text {-test } \\
\text { (male vs female) }\end{array}$ \\
\hline \multirow[t]{3}{*}{ PEOU1 } & male & $4.93(1.14)$ & 6.41 & \multirow[t]{3}{*}{0.002} \\
\hline & female & $4.37(1.04)$ & 3.50 & \\
\hline & overall & $4.58(1.11)$ & 6.65 & \\
\hline \multirow[t]{3}{*}{ PEOU2 } & male & $5.03(1.06)$ & 7.58 & \multirow[t]{3}{*}{0.002} \\
\hline & female & $4.50(1.06)$ & 4.68 & \\
\hline & overall & $4.70(1.09)$ & 8.16 & \\
\hline \multirow[t]{3}{*}{ PEOU3 } & male & $4.74(1.28)$ & 4.51 & \multirow[t]{3}{*}{0.006} \\
\hline & female & $4.17(1.24)$ & $1.39 *$ & \\
\hline & overall & $4.39(1.28)$ & 3.85 & \\
\hline \multirow[t]{3}{*}{ PEOU4 } & male & $4.89(1.02)$ & 6.79 & \multirow[t]{3}{*}{0.060} \\
\hline & female & $4.58(0.96)$ & 5.98 & \\
\hline & overall & $4.70(0.99)$ & 8.87 & \\
\hline \multirow[t]{3}{*}{ PU1 } & male & $5.28(1.10)$ & 9.10 & \multirow[t]{3}{*}{0.421} \\
\hline & female & $5.13(1.12)$ & 10.03 & \\
\hline & overall & $5.19(1.11)$ & 13.52 & \\
\hline \multirow[t]{3}{*}{ PU2 } & male & $5.02(1.13)$ & 7.01 & \multirow[t]{3}{*}{0.885} \\
\hline & female & $5.04(0.97)$ & 10.59 & \\
\hline & overall & $5.03(1.03)$ & 12.58 & \\
\hline \multirow[t]{3}{*}{ PU3 } & male & $5.34(1.08)$ & 9.73 & \multirow[t]{3}{*}{0.537} \\
\hline & female & $5.23(1.09)$ & 11.20 & \\
\hline & overall & $5.28(1.08)$ & 14.85 & \\
\hline \multirow[t]{3}{*}{ PU4 } & male & $5.07(1.00)$ & 8.34 & \multirow[t]{3}{*}{0.267} \\
\hline & female & $4.87(1.15)$ & 7.50 & \\
\hline & overall & $4.94(1.09)$ & 10.89 & \\
\hline
\end{tabular}

Note. $p$-value $=<0.001, * p$-value $=0.168$

Unpaired $t$-tests were performed on items of attitude towards the use of advanced business software application and behavioural intention to use the software using gender as the grouping variable. Results of the $t$-tests showed no significant difference between the mean scores of all attitude and behavioural intention items of the male group and those of the female group ( $t$-values $\leq 1.32, p>0.05$ ). The mean scores of attitude items ranged from 4.73 to 5.18 , whereas the mean scores of behavioural intention items ranged from 4.78 to 5.01. All mean scores were significantly greater than the midpoint of $4.0(p<0.001)$.

When unpaired $t$-tests were performed using year of study as the grouping variable and ANOVAs were performed using age group, specialisation or place of residence as the group variable, the results indicated no significant effect of these demographic variables on the mean scores of all measurement items. Hence, confirmatory factor analysis and structural equation modeling were not carried out separately for different demographic groups.

Confirmatory factor analysis was performed with IBM SPSS AMOS 24.0. A four-factor measurement model comprising perceived ease of use, perceived usefulness, attitude towards the use of advanced business application software, and behavioural intention to use the software produced the following fit indices: $\chi^{2} / d f=1.64\left(\chi^{2}=137.7 ; d f=84 ; p<0.001\right)$, NNFI $=0.95, \mathrm{CFI}=0.96$, and RMSEA $=0.06$. Hence, the measurement model fitted the data well. However, a single-factor model produced the following fit indices: $\chi^{2} / d f=6.34\left(\chi^{2}=570.1 ; d f=90 ; p<0.001\right), \mathrm{NNFI}=0.62, \mathrm{CFI}=0.68$, and RMSEA $=018$. Change 
in $\chi^{2}$ between the four-factor model and single-factor model was significant $\left(\triangle \chi^{2}=432.4 ; \triangle d f=6 ; p<\right.$ 0.001 ), thereby demonstrating that the four-factor model should be used. Table 4 shows composite reliabilities (CR) and average variance extracted (AVE) values of the four constructs, and correlations between these constructs. The AVE values of the constructs were greater than 0.5 , implying adequate convergent validity for the constructs (Fornell \& Larcker, 1981). Moreover, the square root of the AVE value of each construct was greater than the correlations between this construct and other constructs, thereby supporting discriminant validity (Chin, 1998; Fornell \& Larcker, 1981).

Table 4

Mean values, CR, AVE values, and correlations

\begin{tabular}{lccccccc}
\hline Construct & $M(S D)$ & $C R$ & AVE & PEOU & PU & ATT & BI \\
\hline Perceived ease of use (PEOU) & $4.59(0.99)$ & 0.90 & 0.70 & 0.84 & & & \\
Perceived usefulness (PU) & $5.11(0.91)$ & 0.86 & 0.61 & 0.24 & 0.78 & & \\
Attitude (ATT) & $4.91(0.97)$ & 0.85 & 0.66 & 0.46 & 0.53 & 0.81 & \\
Behavioural Intention (BI) & $4.95(1.00)$ & 0.88 & 0.64 & 0.35 & 0.44 & 0.68 & 0.80 \\
\hline
\end{tabular}

Note. The italicised values on the diagonal are the square root of AVE values and the off-diagonal values are correlations between the constructs.

Structural equation modeling was also performed using the maximum likelihood algorithm. Results indicated that perceived ease of use was positively related to perceived usefulness $(\beta=0.37, p<0.001)$; thus, H1 was supported. Moreover, perceived ease of use was positively related to attitude towards the use of advanced business application software $(\beta=0.42, p<0.001)$, perceived usefulness was positively related to attitude towards the use of advanced business application software $(\beta=0.49, p<0.001)$, attitude towards the use of advanced software application was strongly positively related to behavioural intention to use the software $(\beta=0.71, p<0.001)$, and perceived usefulness was weakly significantly positively related to behavioural intention to use the software $(\beta=0.18, p<0.05)$. Hence, H2, H3, H4, and H5 were supported. Figure 2 shows the final structural model of the study. For the clarity of figure, error terms were not shown. The direct, indirect, and total effects between the factors are given in Table 5.

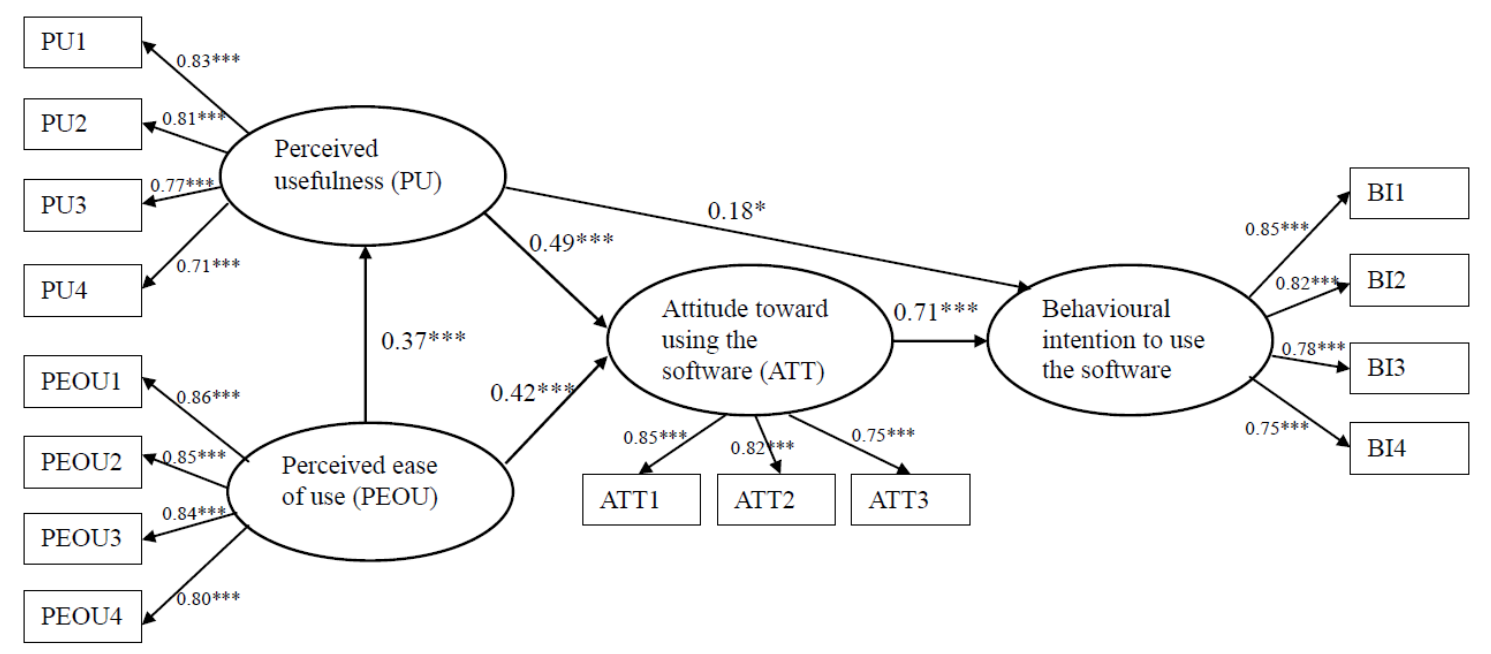

Figure 2. The final structural model of the study

Note. $* p<0.05, * * p<0.01, * * * p<0.001$; Model fit indices: $\chi^{2} / d f=1.63\left(\chi^{2}=138.7 ; d f=85 ; p<0.001\right)$, $\mathrm{NNFI}=0.96, \mathrm{CFI}=0.96$, and $\mathrm{RMSEA}=0.06$ 
Table 5

Direct, indirect, and total effects between the factors

\begin{tabular}{lrrr}
\hline Path & Direct effect & Indirect effect & Total effect \\
\hline PEOU $\rightarrow$ PU & 0.37 & 0 & 0.37 \\
PEOU $\rightarrow$ ATT & 0.42 & 0.18 & 0.60 \\
PEOU $\rightarrow$ BI & 0 & 0.49 & 0.49 \\
PU $\rightarrow$ ATT & 0.49 & 0 & 0.49 \\
PU $\rightarrow$ BI & 0.18 & 0.35 & 0.53 \\
ATT $\rightarrow$ BI & 0.71 & 0 & 0.71 \\
\hline
\end{tabular}

\section{Discussion}

The study results showed that students perceived using the advanced business application software to be rather easy, and they believed that using the software could enhance their course performance. Male students generally rated items of perceived ease of use significantly higher than female students, but no significant difference was found between the ratings of perceived usefulness items by male and female students. The results partly supported the findings of Gefen and Straub (1997), Teo et al. (2015), and Yang and Lester (2005), who reported that males normally rate relatively high scores on perceived ease of use of using ICT technology compared with their female counterparts. Research has found males tend to perceive that they have mastered a computer technology even though they do not understand some critical steps and procedures while females pay great attention to detail and every step or procedure (Downing, Chan, Downing, Kwong, \& Lam, 2008; Shin \& Downing, 2011). Meanwhile, male and female students perceived the software as being equally useful because the means of their ratings were significantly higher than 4. Additionally, there was no significant difference between male and female responses on perceived usefulness, supporting the findings of $\mathrm{Wu}$ and Tsai (2006).

The results of structural equation modeling showed that perceived ease of use was directly related and indirectly related to attitude towards the use of advanced business application software through perceived usefulness, whereas attitude towards the use of the software and perceived usefulness were positively related to behavioural intention to use the software. The fit indices of the structural model met the recommended values (Figure 2), supporting that TAM could be employed to explain business school students' intention to use advanced business application software. The study showed that perceived ease of use is a key determinant of perceived usefulness and attitude towards the use of the software, whilst perceived usefulness affects attitude towards the use of the software. Furthermore, attitude strongly and significantly influences behavioural intention.

Female students generally rated items of perceived ease of use to be much lower than their male counterparts. Specifically, female students rated "learning to use the software was easy for me", "it was easy for me to become skillful at using the software", and "my interaction with the software was clear and understandable" to be significantly much lower than their male counterparts. Thus, faculty members teaching advanced business application software may have to focus their attention to the psychological needs of female students and include interesting examples such as sales and marketing in fashion to reduce female students' anxiety towards using advanced business application software. The formation of perceived ease of use can be enhanced by perceived enjoyment that refers to students' perception of the fun and pleasure derived from using the software (Venkatesh, 2000). Venkatesh (2000) indicated that intrinsic motivation in the form of computer playfulness would also influence users' perceived ease of use and acceptance of the software.

\section{Practical implications}

The study showed that perceived ease of use, perceived usefulness, and attitude towards the use of advanced business application software affected behavioural intention to use the software directly and indirectly. Hence, program director and course instructors must find ways to gauge students' perceptions about ease of use and assist those students who feel overwhelmed or intimidated by learning advanced business application software. Incorporating new instructional technologies such as web-based learning (Bishop \& White 2007; Liang, Wu, \& Tsai, 2011) and new approaches to learning (Bishop 2014) are possible ways to improve students' perceived ease of use and perceived usefulness of an advanced technology. This continual improvement of teaching is particularly important when teaching Chinese students because they are highly 
pragmatic and focus on the experiential aspect and the usefulness of the subjects and degrees they study (Lai, To, Lung, \& Lai, 2012; To, Lung, Lai, \& Lai, 2014). To encourage graduates to develop proficiency in the application of ICT including advanced business application software, higher education institutions should provide appropriate basic computer training and prepare advanced business application software exercises that are relevant to their studies and future jobs to enhance the levels of perceived ease of use and perceived usefulness.

ICT is extensively used in online higher education institutions and online classroom formats, and it is often integrated into the instruction in traditional classrooms, especially in business, finance, mathematics, and engineering (Zieliński, Czekierda, Malawski, Straś, \& Zieliński, 2017). It is essential that ICT is extensively used at the tertiary level, as one of the primary goals of higher education is to prepare students for the employment, and almost all graduates will be confronted with the need to use ICT in their future occupations. Thus, training and motivating students to be competent and comfortable in their use of ICT technology is important for success at the tertiary level. However, the enthusiastic adoption of ICT is often contingent on the usability (which is composed of perceived ease of use and perceived usefulness) of the technology.

It would seem to be counterintuitive that university students would be disinclined to rapidly adopt ICT; within developed societies, individuals who are under the age of 30 have grown up exposed to technology. However, it is this constant exposure to technology that may be the source of the problem when it comes to the adoption of ICT by university students (Anshari, Alas, \& Guan, 2016). The technology to which these millennial students have been most frequently exposed is personal computers, smartphones, and social media platforms, which are all intentionally designed to be as easy to learn and to adapt to as possible (Mesfin, Grønli, Midekso, \& Ghinea, 2016). Thus, when such an individual is confronted with the technology that is more specialised (such as the accounting and e-commerce software packages), and which takes more effort to learn, they may easily become discouraged and avoid using that ICT as much as they can.

It is clear that ICT is often most perceived as usable by students when it is integrated into the classroom in a manner in which they can see it makes their overall learning experience much more efficient and valuable (Henderson, Selwyn, \& Aston, 2015). However, if students perceive that a particular type of ICT is simply being forced on them for arbitrary reasons, they will exhibit resistance to that specific technology, and will be more strongly disinclined to spend time and energy attempting to learn it.

Ultimately, when it comes to efforts to persuade university students to adopt advanced business analysis package and software and to use them extensively throughout their senior years, in particular for their final/graduation projects, it is necessary for the package and software to mimic the most widely used ICT that is currently available on the market for personal use. If students perceive advanced business application software to be very similar to the technology that they have been using their entire lives and that it is close to the technology that they will most likely use in their future careers, they will be more amenable to adopting and using it. However, if the software seems to be too highly specialised even to the university environment, most students will not view it as usable, as they will never encounter it again after graduation.

\section{Limitations of the study}

The study has two main limitations. First, generalisation of the study's findings should be done with caution because the sample of the study was limited to business school students in a higher education institution in Macao, China. Hence, the study's findings may not be applied to students' perceptions towards advanced business application courses in other disciplines and in the non-Chinese environment. Second, we obtained the responses from self-reported questionnaires and common method bias could be a concern. To address this we conducted Harman's 1-factor test, which is a post-hoc statistical test, to assess common method variance using the 15 items shown in Appendix A (Podsakoff, MacKenzie, Lee, \& Podsakoff, 2003). The results of Harman's 1-factor test showed that no single factor emerged that accounted for the majority of variance, implying that the common method bias was not an issue in the study. 


\section{Conclusions}

Our study investigated students' perceptions towards advanced business application software with regard to its ease of use and usefulness in learning and mastering business knowledge. On the basis of the responses from 159 Chinese business school students, we found that students believed that using advanced business application software was free from effort and using the technology could enhance their academic performance. Although ICT is ubiquitous in students' personal lives, female students still rated perceived ease of use lower than their male counterparts. The study also provided evidence that TAM can explain students' intention to use advanced business application software in the Chinese context.

\section{Acknowledgment}

We would like to thank the two anonymous reviewers for their valuable comments and suggestions that improved the quality of this paper.

\section{References}

Ajzen, I. (1985). From intentions to actions: A theory of planned behavior. In J. Kuhl, \& J. Beckmann (Eds.), Action-control: From cognition to behavior (pp.11-39). Heidelberg: Springer.

Anshari, M., Alas, Y., \& Guan, L. S. (2016). Developing online learning resources: Big data, social networks, and cloud computing to support pervasive knowledge. Education and Information Technologies, 21(6), 1663-1677. https://doi.org/10.1007/s10639-015-9407-3

Asai, T. (2011). Application of ICT in career preparation program. Bulletin of Hokusho University School of Lifelong Learning Support Systems, 11(3), 35-42.

Atif, A., Richards, D., Busch, P., \& Bilgin, A. (2015). Assuring graduate competency: A technology acceptance model for course guide tools. Journal of Computing in Higher Education, 27(2), 94-113. https://doi.org/10.1007/s12528-015-9095-4

Ballantine, J. A., Larres, P. M., \& Oyelere, P. (2007). Computer usage and the validity of self-assessed computer competence among first-year business students. Computers \& Education, 49(4), 976-990. https://doi.org/10.1016/j.compedu.2005.12.001

Behrend, T. S., Wiebe, E. N., London, J. E., \& Johnson, E. C. (2011). Cloud computing adoption and usage in community colleges. Behaviour \& Information Technology, 30(2), 231-240. https://doi.org/10.1080/0144929X.2010.489118

Bishop, M. J. (2014). Instructional message design: Past, present, and future relevance. In J. M. Spector, M. D. Merrill, J. Elen, \& M. J. Bishop (Eds.), Handbook for research in educational communications and technology (4th ed.) (pp. 373-383). New York, NY: Springer. https://doi.org/10.1007/978-1-4614$\underline{3185-5 \quad 30}$

Bishop, M. J., \& White, S. A. (2007). The Clipper project: Discovering what online courses offer residential universities. Educause Quarterly, 30(1), 14-20.

Celik, H. E., \& Yilmaz, V. (2011). Extending the technology acceptance model for adoption of e-shopping by consumers in Turkey. Journal of Electronic Commerce Research, 12(2), 152-164.

Chau, P. Y. K. (1996). An empirical assessment of a modified technology acceptance model. Journal of Management Information Systems, 13(2), 185-204. https://doi.org/10.1080/07421222.1996.11518128

Chau, P. Y. K. (2001). Influence of computer attitude and self-efficacy on IT usage behavior. Journal of End User Computing, 13(1), 26-33. https://doi.org/10.4018/joeuc.2001010103

Chin, W. W. (1998). Issues and opinion on structural equation modeling. MIS Quarterly, 22(1), vii-xvi.

Chiu, Y. L., \& Tsai, C. C. (2014). The roles of social factor and internet self-efficacy in nurses' web-based continuing learning. Nurse Education Today, 34(3), 446-450. https://doi.org/10.1016/j.nedt.2013.04.013

Creighton, W., Kilcoyne, M., Tarver, R., \& Wright, S. (2006). Computer literacy levels of students enrolling in a post-secondary computer applications/information technology course. Information Technology, Learning, and Performance Journal, 24(1), 15-23.

Davis, F. D. (1989). Perceived usefulness, perceived ease of use, and user acceptance of information technology. MIS Quarterly, 13(3), 319-340. https://doi.org/10.2307/249008

Davis, F. D., Bagozzi, R. P., \& Warshaw, P. R. (1989). User acceptance of computer technology: A comparison of two theoretical models. Management Science, 35(8), 982-1003. https://doi.org/10.1287/mnsc.35.8.982 
Dillon, A., \& Morris, M. G. (1996). User acceptance of new information technology: Theories and models. Annual Review of Information Science and Technology, 31, 3-32.

Dishaw, M. T., \& Strong, D. M. (1999). Extending the technology acceptance model with tasktechnology fit constructs. Information \& Management, 36(1), 9-21. https://doi.org/10.1016/S03787206(98)00101-3

Downing, K., Chan, S. W., Downing, W. K., Kwong, T., \& Lam, T. F. (2008). Measuring gender differences in cognitive functioning. Multicultural Education \& Technology Journal, 2(1), 4-18. https://doi.org/10.1108/17504970810867124

Edmunds, R., Thorpe, M., \& Conole, G. (2012). Student attitudes towards and use of ICT in course study, work and social activity: A technology acceptance model approach. British Journal of Educational Technology, 43(1), 71-84. https://doi.org/10.1111/j.1467-8535.2010.01142.x

Fathali, S., \& Okada, T. (2018). Technology acceptance model in technology-enhanced OCLL contexts: A self-determination theory approach. Australasian Journal of Educational Technology, 34(4), 138-154. https://doi.org/10.14742/ajet.3629

Fenech, T. (1998). Using perceived ease of use and perceived usefulness to predict acceptance of the world wide web. Computer Networks and ISDN Systems, 30(1), 629-630. https://doi.org/10.1016/S0169-7552(98)00028-2

Fishbein, M., \& Ajzen, I. (1975). Belief, attitude, intention and behavior: An introduction to theory and research. Reading, MA: Addison-Wesley.

Fitzgerald, M. A. (2004). Making the leap from high school to college. Knowledge Quest, 32(4), 19-24.

Fornell, C., \& Larcker, D. F. (1981). Evaluating structural equation models with unobservable variables and measurement error. Journal of Marketing Research, 18(1), 39-50. https://doi.org/10.2307/3151312

Gainey, T. W., \& Sanchez, M. S. (2013). Foundations of computer applications for college students: A moving target. International Journal of Instructional Technology and Distance Learning, 10(11), 1524.

Gefen, D., \& Straub, D. W. (1997). Gender differences in the perception and use of e-mail: An extension to the technology acceptance model. MIS Quarterly, 21(4), 389-400.

Goodhue, D. L., \& Thompson, R. L. (1995). Task-technology fit and individual performance. MIS Quarterly, 19(2), 213-236.

Gosper, M., Malfroy, J., \& McKenzie, J. (2013). Students' experiences and expectations of technologies: An Australian study designed to inform planning and development decisions. Australasian Journal of Educational Technology, 29(2), 268-282. https://doi.org/10.14742/ajet.127

Gu, J. C., Lee, S. C., \& Suh, Y. H. (2009). Determinants of behavioral intention to mobile banking. Expert Systems with Applications, 36(9), 11605-11616. https://doi.org/10.1016/j.eswa.2009.03.024

Hair, J. F. Jr., Anderson, R. E., Tatham, R. L., \& Black, W. C. (2006). Multivariate data analysis (6th ed.) Englewood Cliffs: Prentice Hall.

Hayes, D. C., Cook, M., \& LaRosa, D. (2011). One ticket to the matinee please: A case designed to teach students accounting software (Peachtree) skills. AIS Educator Journal, 6(1), 59-65. https://doi.org/10.3194/1935-8156-6.1.59

Henderson, M., Selwyn, N., \& Aston, R. (2015). What works and why? Student perceptions of 'useful' digital technology in university teaching and learning. Studies in Higher Education, 42(8), 1567-1579. https://doi.org/10.1080/03075079.2015.1007946

Hooper, D., Coughlan, J., \& Mullen, M. (2008). Structural equation modelling: Guidelines for determining model fit. Electronic Journal of Business Research Methods, 6(1), 53-60.

Hu, L. T., \& Bentler, P. M. (1999). Cutoff criteria for fit indexes in covariance structure analysis: Conventional criteria versus new alternatives. Structural Equation Modeling: A Multidisciplinary Journal, 6(1), 1-55. https://doi.org/10.1080/10705519909540118

Im, I., Kim, Y., \& Han, H. J. (2008). The effects of perceived risk and technology type on users' acceptance of technologies. Information \& Management, 45(1), 1-9. https://doi.org/10.1016/j.im.2007.03.005

Juan, C. F., She, H. I., Hung, C. Y., Lee, S. W. Y., Liang, J. C., Chang, K. E., \& Tsai, C. C. (2018). Exploring the relationships between EFL learners' usage of technology and their approaches to learning English. Proceedings of the 1st International Conference on Innovative Technologies and Learning, Portoroz, Slovenia, 412-420. https://doi.org/10.1007/978-3-319-99737-7_44

Lai, L. S. L., To, W. M., Lung, J. W. Y., \& Lai, T. M. (2012). The perceived value of higher education: The voice of Chinese students. Higher Education, 63(3), 271-287. https://doi.org/10.1007/s10734$\underline{011-9439-6}$ 
Lederer, A. L., Maupin, D. J., Sena, M. P., \& Zhuang, Y. (2000). The technology acceptance model and the World Wide Web. Decision Support Systems, 29(3), 269-282. https://doi.org/10.1016/S01679236(00)00076-2

Lee, C. C., Cheng, H. K., \& Cheng, H. H. (2007). An empirical study of mobile commerce in insurance industry: Task-technology fit and individual differences. Decision Support Systems, 43(1), 95-110. https://doi.org/10.1016/j.dss.2005.05.008

Liang, J. C., Wu, S. H., \& Tsai, C. C. (2011). Nurses' Internet self-efficacy and attitudes toward webbased continuing learning. Nurse Education Today, 31(8), 768-773. https://doi.org/10.1016/j.nedt.2010.11.021

Mandal, P., Flosi, A., \& Large, J. (2016). Paradigm shift in teaching IT-based courses in a teaching university. International Journal of Business Information Systems, 21(3), 342-352. https://doi.org/10.1504/IJBIS.2016.074765

Maria de Fátima, D., \& Alves, L. A. (2007). The implementation and use of computers in education in Brazil: Niterói city/Rio de Janeiro. Computers \& Education, 49(4), 1378-1386. https://doi.org/10.1016/j.compedu.2006.03.002

McCloskey, D. W., \& Bussom, L. (2013). Active learning and student engagement in the business curriculum: Excel can be the answer. Journal of Learning in Higher Education, 9(2), 1-12.

Mesfin, G., Grønli, T. M., Midekso, D., \& Ghinea, G. (2016). Towards end-user development of REST client applications on smartphones. Computer Standards \& Interfaces, 44, 205-219.

Muk, A., \& Chung, C. (2015). Applying the technology acceptance model in a two-country study of SMS advertising. Journal of Business Research, 68(1), 1-6. https://doi.org/10.1016/j.jbusres.2014.06.001

Nunnally, J. C., \& Bernstein, I. H. (1994). Psychometric theory (3rd ed.). New York, NY: McGraw-Hill.

Park, S. Y., Nam, N. W., \& Cha, S. B. (2012). University students' behavioral intention to use mobile learning: Evaluating the technology acceptance model. British Journal of Educational Technology, 43(4), 592-605. https://doi.org/10.1111/j.1467-8535.2011.01229.x

Podsakoff, P. M., MacKenzie, S. B., Lee, J. Y., \& Podsakoff, N. P. (2003). Common method biases in behavioral research: A critical review of the literature and recommended remedies. Journal of Applied Psychology, 88(5), 879-903. https://doi.org/10.1037/0021-9010.88.5.879

Roberts, P., \& Henderson, R. (2000). Information technology acceptance in a sample of government employees: A test of the technology acceptance model. Interacting with Computers, 12(5), 427-443. https://doi.org/10.1016/S0953-5438(98)00068-X

Shin, K., \& Downing, K. (2011). User centred e-learning platform design. Proceedings of the 2011 Conference on Designing Pleasurable Products and Interfaces, Association of Computing Machinery, Politecnico de Milano, Milan.

Shroff, R. H., Deneen, C. C., \& Ng, E. M. W. (2011). Analysis of the technology acceptance model in examining students' behavioural intention to use an e-portfolio system. Australasian Journal of Educational Technology, 27(4), 600-618. https://doi.org/10.14742/ajet.940

Teer, H. B., Teer, F. P., \& Kruck, S. E. (2007). A study of the database marketing course in AACSBaccredited business schools. Journal of Marketing Education, 29(3), 245-253. https://doi.org/10.1177/0273475307306891

Teo, T. (2008). Pre-service teachers' attitudes towards computer use: A Singapore survey. Australasian Journal of Educational Technology, 24(4), 413-424. https://doi.org/10.14742/ajet.1201

Teo, T., Fan, X., \& Du, J. (2015). Technology acceptance among pre-service teachers: Does gender matter? Australasian Journal of Educational Technology, 31(3), 235-251. https://doi.org/10.14742/ajet.1672

To, W. M., Lung, J. W. Y., Lai, L. S. L., \& Lai, T. M. (2014). Destination choice of cross-border Chinese students: an importance-performance analysis. Educational Studies, 40(1), 63-80. https://doi.org/10.1080/03055698.2013.858615

To, W. M., \& Tang, M. N. F. (2019). Computer-based course evaluation: An extended technology acceptance model. Educational Studies, 45(2), 131-144. https://doi.org/10.1080/03055698.2018.1443797

United Nations Educational, Scientific and Cultural Organization (2014). Information and communication technology (ICT) in education in Asia - A comparative analysis of ICT integration and e-readiness in Schools across Asia. United Nations Educational, Scientific and Cultural Organization Institute for Statistics, Canada.

Venkatesh, V. (2000). Determinants of perceived ease of use: Integrating control, intrinsic motivation, and emotion into the technology acceptance model. Information Systems Research, 11(4), 342-365.

https://doi.org/10.1287/isre.11.4.342.11872 
Wong, K. T., Teo, T., \& Russo, S. (2012). Influence of gender and computer teaching efficacy on computer acceptance among Malaysian student teachers: An extended technology acceptance model. Australasian Journal of Educational Technology, 28(7), 1190-1207. https://doi.org/10.14742/ajet.796

Wu, Y. T., \& Tsai, C. C. (2006). University students' Internet attitudes and internet self-efficacy: A study at three universities in Taiwan. Cyberpsychology \& Behavior, 9(4), 441-450. https://doi.org/10.1089/cpb.2006.9.441

Yang, B., \& Lester, D. (2005). Gender differences in e-commerce. Applied Economics, 37(18), 20772089. https://doi.org/10.1080/00036840500293292

Youszfzai, S., Foxall, G. R., \& Pallister, J. G. (2010). Explaining internet banking behavior: Theory of reasoned action, theory of planned behavior, or technology acceptance model? Journal of Applied Social Psychology, 40(5), 1172-1202. https://doi.org/10.1111/j.1559-1816.2010.00615.x

Zieliński, K., Czekierda, Ł., Malawski, F., Straś, R., \& Zieliński, S. (2017). Recognizing value of educational collaboration between high schools and universities facilitated by modern ICT. Journal of Computer Assisted Learning, 33(6), 633-648. https://doi.org/10.1111/jcal.12207

Corresponding author: Wai-Ming To, wmto@ipm.edu.mo

Please cite as: To, W. M., Lai, L. S. L., \& Leung, V. W. S. (2019). Technology acceptance model for the intention to use advanced business application software among Chinese business school students. Australasian Journal of Educational Technology, 35(4), 160-173. https://doi.org/10.14742/ajet.4942 


\section{Appendix A \\ Items of perceived ease of use, perceived usefulness, attitude towards the use of the software, and behavioral intention to use the software and factor loadings obtained from CFA}

Perceived ease of use (PEOU)

PEOU1 It was easy for me to become skillful at using the software.

0.86

PEOU2

My interaction with the software was clear and understandable.

0.85

PEOU3

Learning to use the software was easy for me.

0.84

PEOU4

I found the software to be flexible to interact with.

0.80

Perceived usefulness (PU)

PU1 Using the software increased productivity in my coursework.

PU2 Using the software improved my course (and study) performance.

PU3

Using the software enabled me to accomplish tasks quickly.

0.77

PU4

Using the software enhanced my effectiveness in mastering business knowledge.

0.71

Attitude towards the use of the software (ATT)

ATT1 Overall, I enjoyed using the software.

ATT2

Using the software provided me with much enjoyment.

ATT3

I like the idea of using the software.

Behavioural intention to use the software (BI)

BI1 I intend to use the software frequently for my coursework.

BI3

I intend to use the software during the study period.

0.78

BI4

I plan to use the software in future jobs. 